Корнівська В. О., д.е.н. ДУ «Інститут економіки та прогнозування Національної академії наук України» м. Київ, Україна

DOI: https://doi.org/10.30525/978-9934-26-064-3-3

\title{
ПРОЯВИ СУПЕРЕЧНОСТІ ГЛОБАЛІЗАЦІЇ І ЛОКАЛІЗАЦІЇ У ФІНАНСОВО-ІНСТИТУЦЙНОМУ ПРОСТОРІ
}

Еволюція суспільних, економічних систем може бути розкрита у іiі різних аспектах, одним 3 яких є розгортання суперечності між глобалізацією та локалізацією. За методологією д.е.н. Гриценка А.А. суперечність між глобалізацією і локалізацією представляє собою найзагальнішу форму прояву суперечності сумісно-розділених відносин. При цьому глобалізація «розвивається $з$ боку сумісності й реалізується, перш за все, через інформаційно-технологічні та фінансово-економічні механізми», локалізація «розвивається 3 боку роздільності й реалізується через просторово-територіальні форми» [1, с. 10]. Глобалізація розвивається також в управлінських формах, у спрямуванні представників наднаціональних інститутів до формування основ 
глобального управління. Локалізація розвивається як відповідь інституційних середовищ на дані намагання.

Багато феноменів та явищ, що сьогодні розвиваються в умовах активізації цифрової трансформації, є нічим іншим як відображенням єдності та суперечності глобалізації та локалізації. Наочним прикладом емпіричного відображення практичної цінності теоретико-методологічного підходу до розвитку економічних систем у контексті суперечливої єдності глобалізації та локалізації є сучасні епідеміологічні проблеми, що маючи витоки у локальній системі координат стали викликом для світового суспільства. Водночас кожна країна, реалізуючи загальні принципи боротьби із коронакризою, показала особливості заходів у галузі охорони здоров'я, соціальної та економічної політики. I кожна з цих країн отримала різні результати. Якщо Китай вже у третьому кварталі 2020 року, доводячи дієвість державної політики, активність громадянського суспільства та спроможність бізнесу до відновлення, демонстрував нормальну роботу основної маси підприємств, то у Сполучених Штатах відбувалося значне скорочення виробничого потенціалу (найбільше з 1947 року), виручка малого бізнесу скоротилася на 30\%.

У системі регулювання суперечності глобалізації та локалізації розкриваються у складності впровадження єдиних принципів операційної активності у різних інституційних середовищах. У фінансово-інституційному просторі суперечності глобалізації та локалізації проявляються сьогодні у тому, що на тлі посилення макропруденційного регулювання, впровадження комплаєнсу, стає все більше нерегульованих, або мало регульованих просторів циркуляції ліквідності, при цьому обсяги тіньового банкінгу зростають. Інституційне середовище фінансового простору завжди дає непередбачувані відповіді на спроби впровадження єдиного глобального управління.

Термін «тіньової банк» вперше був використаний економістом Полом Маккаллі в 2007 році. Маккаллі зазначив, що тіньові банки, не будучи банками у повному сенсі, виконують ті ж операції, що й банківські структури, але не підпадають під 
банківське регулювання. Вони залучають короткострокові кошти на грошових ринках і використовують ці кошти для купівлі активів 3 довгостроковими термінами погашення. Але, оскільки вони не підпадають під традиційне банківське регулювання, то в надзвичайних ситуаціях вони не можуть, на відміну від банків, брати позики у Федеральної резервної системи і не мають традиційних вкладників, кошти яких покриваються страховкою; вони в «тіні» [2].

Отже їх діяльність створює істотні системні ризики. Саме непрозорий, мало регульований тіньовий банкінг став однією 3 причин світової фінансової кризи 2008-2009 pp., і сьогодні держави докладають значних зусиль для розширення макропруденційного впливу в цій частині фінансового простору. Його основними операторами є пенсійні фонди, страхові корпорації та інші фінансові посередники. Станом на 2019 рік їх фінансові активи склали 200,2 трлн дол, що становить майже половину світової фінансової системи, в порівнянні з 42\% в 2008 році. Ключовим фактором зростання небанківських фінансових установ було розширення механізмів колективного інвестування, таких як хедж-фонди та інші інвестиційні фонди. В період 3 2013 по 2019 рік активи цих компаній зростали в середньому на $11 \%$ в рік і склали $31 \%$ сектора небанківських фінансових установ [2].

Головними причинами зростання обсягів операцій небанківських фінансових установ, що складають основу тіньового банкінгу, є посилення банківського регулювання та низькі відсоткові ставки, що змушують розвивати небанківський фінансовий сектор.

Моніторинг небанківського фінансового посередництва за 2019 рік, представлений Радою 3 фінансової стабільності, що охоплює дані з 29 юрисдикцій, які разом представляють понад $80 \%$ світового ВВП, доводить зростання кредитування з боку цих фінансових установ, особливо у зоні євро [3].

Таким чином, глобальні тенденції посилення банківського регулювання призвели до активізації інших локальних секторів 
фінансово-інституційного простору, таких як небанківські фінансові установи, що заміщаючи банківських посередників, створюють значний потенціал системних ризиків. Водночас реалізована сьогодні політика низьких відсоткових ставок навряд чи дозволить подолати цю структурну розбалансованість. Більше того, до сих пір еволюція фінансового посередництва доводила, що долання регулюючих обмежень $є$ нормою операційної активності фінансових установ, спрямованої на досягнення максимальної прибутковості операцій. Едвард Кейн ввів поняття «діалектики регулювання», коли державні органі розробляють принципи, правила, норми діяльності, а фінансові інститути створюють інноваційні продукти для виходу за межі нормативів i таким чином функціонують у напіврегульованому просторі операційної активності, поки держава знову не впорядкує їх діяльність. Сьогодні це вже не інноваційні продукти, а інноваційна діяльність секторів, що створює значні ризики для традиційного банкінгу.

Поряд із відсутністю ефективного нагляду та прозорості головний ризик тіньової банківської системи полягає у єдності 3 традиційними банками. Багато найбільших банків світу ведуть тіньовий банківський бізнес (бізнес інвестиційного банку) i роздрібний бізнес (традиційний банківський бізнес) під одним дахом. Перебування тіньової банківської сторони бізнесу під загрозою через брак ліквідності становить значний ризик для роздрібного банківського обслуговування, де зберігаються заощадження вкладників [4].

Методологічний підхід аналізу економічних процесів у контексті суперечності глобалізації та локалізації дає можливості щодо оцінки дієвості тих чи інших заходів економічної політики, регулюючих процедур. Сучасний глобальний тренд стимулюючої монетарної політики доводить свою суперечливість уже тому, що призводить до істотного розбалансування у системі фінансового посередництва та деформацій його локальних структур, таким чином він має бути переглянутим для забезпечення ефективного подолання сучасних кризових процесів. 


\section{Література:}

1. Інституційні трансформації соціально-економічної системи України : монографія / за ред. чл.- кор. НАН України Гриценка А.А.; НАН України, ДУ «Ін-т екон. та прогнозування НАН України». Київ, 2015. 274 с.

2. Laura E. Kodres. Shadow Banks: Out of the Eyes of Regulators. URL: https://www.imf.org/external/pubs/ft/fandd/basics/52-shadow-banking.htm

3. Global Monitoring Report on Non-Bank Financial Intermediation 2019, 19 January 2020. URL: https://www.fsb.org/wp-content/uploads/P190120.pdf

4. The-shadow-banking-system. URL: http://prudentpress.com/finance/the-shadow-banking-system 